\title{
Digitisasi Arsip sebagai Upaya Perlindungan Arsip Vital Milik Keluarga Dusun Punukan, Wates, Kulonprogo, Daerah Istimewa Yogyakarta
}

\author{
${ }^{1}$ Lastria Nurtanzila, ${ }^{2}$ Faizatush Sholikhah \\ ${ }^{1,2}$ Universitas Gadjah Mada
}

\begin{abstract}
Family records are records of activities that is created or stored by the family in any media form which are useful for family activities. Society's concern for family records often goes unnoticed, and sometimes these records do not receive the protection they deserves. Departing from anxiety about the possibility of disasters and risks that exist in Indonesia, we feel the need for socialization about the records through the digitization method. The method used in this research is a qualitative method with a case study approach. The case study is based on in-depth research on the tendency of family behavior in Punukan, Wates, Kulon Progo in managing family records. This research has produced several findings which were lessons learned that can be used as examples for other regions. Some of these lessons are ; first; record management awareness needs to be built from an early age; second; there needs to be a role for the local government (Archives and Library Agency) in an effort to disseminate awareness of records management; third; limited public information literacy greatly hampers understanding of the urgency of records management; fourth; records storage media is still very limited. So that the role of the community service programs of the Archival Science Study Program, Universitas Gadjah Mada for 3 years in Punukan Hamlet, Wates, Kulon Progro are greatly beneficial.
\end{abstract}

\section{INTISARI}

Arsip keluarga merupakan rekaman kegiatan dan atau informasi yang diciptakan atau disimpan oleh keluarga dalam berbagai bentuk media sesuai perkembangan jaman dan berguna bagi kegiatan keluarga. Perhatian terhadap arsip keluarga sering luput dari perhatian kita, dan tidak mendapatkan perlindungan yang layak. Berangkat dari kegelisahan pada kemungkinan bencana dan resiko yang hadir di Indonesia, peneliti merasa perlunya ada sosialisasi tentang pentingnya arsip keluarga dan upaya perlindungan terhadap arsip-arsip tersebut. Dalam penelitian ini, peneliti mencoba mengamati tentang upaya perlindungan arsip keluarga melalui metode digitisasi. Metode yang digunakan dalam penelitian ini adalah metode kualitatif dengan pendekatan studi kasus. Studi kasus yang dimaksudkan adalah dengan meneliti secara mendalam terhadap kecenderungan perilaku keluarga di Dusun Punukan, Wates, Kulon Progo dalam melakukan pengelolaan arsip keluarga.Penelitian ini menghasilkan beberapa temuan berupa pelajaran penting yag didapatkan yang bisa digunakan sebagai contoh bagi daerah-daerah lainnya. Beberapa pelajaran tersebut yaitu pertama; kesadaran pengelolaan arsip perlu dibangun sedari dini; kedua; perlu ada peran serta dinas arsip dan perpustakaan setempat dalam upaya sosialisasi kesadaran pengelolaan arsip; ketiga; literasi informasi masyarakat yang masih terbatas sangat menghambat pemahaman tentang urgensi pengelolaan arsip; keempat; media penyimpanan arsip masih sangat terbatas. Sehingga peranan program pengabdian masyarakat Prodi Kearsipan Sekolah Vokasi UGM selama 3 tahun di Dusun Punukan, Wates, Kulon Progro sangatlah bermanfaat.
Submitted: $22 / 2 / 2021$

Received: 28/2/2021

*Correspondence: Lastria Nurtanzila lastrianurtanzila@ugm.ac.id

KEYWORDS: arsip keluarga

Digitisasi

perlindungan arsip vital

KATA KUNCI: family recods digitization

protection of vital records

CITE THIS ARTICLE:

Nurtanzila, L., Sholikhah, F. (2020). Dititisasi Arsip sebagai Upaya

Perlindungan Arsip Vital Milik Keluarga Dusun Punukan, Wates,

Kulonprogo, Daerah Istimewa Yogyakarta. Jurnal Diplomatika, 4(1), 57-65. 


\section{PENDAHULUAN}

Kegiatan kearsipan bukan hanya menjadi milik instansi formal saja, namun juga merupakan ranah pengelolaan pribadi. Berdasarkan Undang - Undang No 43 Tahun 2009 Tentang Kearsipan (Republik Indonesia, 2009) bahwa yang dimaksud dengan arsip yaitu:

"Arsip adalah rekaman kegiatan atau peristiwa dalam berbagai bentuk dan media sesuai dengan perkembangan teknologi informasi dan komunikasi yang dibuat dan diterima oleh lembaga negara, pemerintah daerah, lembaga pendidikan, perusahaan, organisasi politik, organisasi kemasyarakatan, dan perseorangan dalam pelaksanaan kehidupan bermasyarakat, berbangsa, dan bernegara".

Melihat pengertian diatas dapat dipahami bahwa arsip sendiri merupakan seluruh rekaman kegiatan, hal ini juga dapat diaplikasikan dalam kegiatan keluarga sebagai institusi terkecil dalam sebuah struktur organisasi kenegaraan. Setiap keluarga pastinya akan menyimpan sejumlah rekaman kegiatan dan atau bukti kepemilikan yang diangggap pneting bagi keluarga tersebut dan bagi kegiatan dalam keluarga tersebut. Manajemen arsip keluarga yang baik dapat mendorong jalannya kegiatan keluarga yang lebih lancar. Tidak dapat dipungkiri bahwa kegiatan mengarsipkan ini sudah terjadi sejak seorang individu terlahir di dunia ini, seperti ketika seseorang lahir maka akan tercipta arsip bukti kelahiran, begitu juga kelak ketika sesorang beranjak dewasa dan masuk jenjang pendidikan maka akan tercipta arsip pendidikan dan lain sebagainya.

Arsip-arsip keluarga ini juga memiliki fungsi sebagai indentitas personal, sering juga digunakan konsep arsip personal. Salah satu nilai guna arsip personal adalah nilai guna bukti keberadaan (evidential).

"arsip yang bernilai guna kebuktian (evidential) adalah arsip yang mempunyai nilai isi informasi yang mengandung fakta dan keterangan yang dapat digunakan untuk menjelaskan bagaimana lembaga negara, pemerintah daerah, lembaga pendidikan, perusahaan, organisasi politik, organisasi kemasyarakatan dibentuk, dikembangkan, digabung, dibubarkan diatur serta dilaksanakannya fungsi dan tugas." Sattar (2019)

Selain itu, arsip personal ini juga memiliki nilai guna informasional, yang berarti didalamnya terkandung informasi yang juga mengandung kegunaan untuk berbagai kepentingan pemilik arsip.

"arsip yang bernilai guna informasional adalah arsip yang mempunyai nilai isi informasi yang mengandung kegunaan untuk berbagai kepentingan penelitian dan kesejarahan tanpa dikaitkan dengan lembaga/instansi penciptanya, yaitu informasi mengenai orang, tempat, benda, fenomena, masalah, dan sejenisnya." Sattar (2019)

Berangkat dari pentingnya nilai guna arsip keluarga tersebut maka perlu dilakukan perlindungan terhadap jenis-jenis arsip ini. Beberapa dari arsip tersebut juga termasuk dalam arsip vital, arsip vital sendiri merupakan arsip yang sangat penting. Berdasarkan Perka ANRI N0.6 Tahun 2005, arsip vital diartikan sebagai;

"informasi terekam yang sangat penting dan melekat pada keberadaan dan kegiatan organisasi yang di dalamnya mengandung informasi mengenai status hukum, hak dan kewajiban serta asset (kekayaan) instansi. Apabila dokumen/ arsip vital hilang tidak dapat diganti dan mengganggu/menghambat keberadaan dan pelaksanaan kegiatan instansi" 
Pentingnya arsip vital perlu mendapat perhatian dari pihak-pihak yang bersangkutan, terutama keluarga penyimpan dari arsip tersebut. Oleh karena itulah dalam kegiatan pengabdian masyarakat yang dilaksanakan Prodi Kearsipan Skeolah Vokasi UGM selama 3 tahun berturut-turut, diputuskan untuk fokus pada peningkatan kesadaran pada pengelolaan arsip keluarga tersebut. Pada tahun 2018, kegiatan pengabdian berfokus pada sosialisasi pentingnya pengelolaan arsip keluarga. Pada tahun 2019, kegiatan pengadian berkembang pada melaksanakan digitisasi arsip keluarga sebagai langkah perlindungan terhadap arsip tersebut. Pada tahun 2020, kegiatan lebih specifik pada pemberian pemahaman bahwa arsip kelurga merupakan arsip vital yang membutuhkan perlindungan, selain itu pada tahun 2020, tim pengabdian juga memberikan sosialiasi bahwa pelaksanaan digitisasi perlu dilakukan secara mandiri dan berkelanjutan. Kegiatan ini dilaksanakan di lokasi yang sama yaitu Dusun Punukan, Wates, Kulonprogo.

Dusun Punukan merupakan salah satu wilayah administratif di Kelurahan Wates, Kecamatan Wates, Kabupaten Kulon Progo, Daerah Istimewa Yogyakarta. Kelurahan Wates merupakan wilayah administratif yang baru dibentuk pada 1 Desember 2010. Luas wilayah Kelurahan Wates adalah 428,2422 Ha. Kelurahan Wates terdiri dari 86 RT dan 16 RW, sebagaimana diatur dalam Keputusan Bupati Kulon Progo Nomor 84/ A/2015 tentang Pengesahan Keputusan Lurah Wates Kecamatan Wates Kabupaten Kulon Progo Nomor 03 Tahun 2015 tentang Perubahan Nomor dan Nama Rukun Tetangga dan Rukun Warga Kelurahan Wates Kecamatan Wates. Kelurahan Wates menjadi salah satu motor penggerak ekonomi di Kabupaten Kulon Progo.

Mengapa tema digitisasi dipilih? karena dalam dunia modern saat ini membawa banyak dampak pada kehidupan sosial dan budaya. Salah satunya adalah perilaku masyarakat dalam menyimpan informasi. Pada saat ini, dengan adanya kemajuan teknologi, informasi tidak hanya disimpan di media konvensional saja namun juga di media elektronik. Usaha dalam melakukan digitisasi terhadap arsip dan dokumen ini juga merupakan salah satu upaya dalam melindungi arsip itu sendiri, sehingga dalam penelitian ini pertanyaan penelitian yang akan dijawab adalah bagaimana penerapan Digitisasi Arsip Sebagai Upaya Perlindungan Arsip Vital Milik Keluarga di Dusun Punukan, Wates, Kulon Progo, Daerah Istimewa Yogyakarta?"

\section{METODE}

Pendekatan yang akan digunakan dalam kegiatan ini adalah menggunakan metode kualitatif deskriptif. Hal ini bertujuan agar data yang didapatkan dapat digunakan untuk menarik kesimpulan atas isu yang dijadikan fokus kajian. Unit analisis yang digunakan adalah individu yaitu, warga Dusun Punukan.

Adapun lokasi penelitian dilakukan di Dusun Punukan itu sendiri, yaitu warga RW 1. Metode pengumpulan data dalam penelitian ini menggunakan beberapa cara, antara lain:

\section{Studi Pustaka}

Metode studi pustaka dilakukan untuk mengumpulkan data sekunder sebanyak mungkin yang berkaitan dengan penelitian ini. Sesuai dengan tujuan dari penelitian ini untuk memahami Penerapan Digitaliasasi Arsip sebagai Upaya Perlindungan Terhadap Arsip Keluarga di Dusun Punukan, Wates, Kulonprogo, maka berbagai literatur dikumpulkan dan dianalisis untuk mendapatkan informasi yang akurat dalam membahas penelitian ini.

2. Observasi

Observasi dilakukan secara langsung, yaitu dengan kegiatan pengabdian yang 
sudah dilaksanakan secara 3 tahun berturut-turut sejak tahun 2018-2020. Kegiatan observasi mulai dari pelaksanan sosialiasasi pada warga, pelatihan, projek digitisasi, pengamatan langsung hingga wawancara kepada pihak-pihak terkait.

\section{HASIL DAN PEMBAHASAN}

Kegiatan digitisasi merupakan kegiatan onversi data dari dokumen kertas forto, mikrofilm, LPs, Film, dan Kaset VHS ke format digital (Savic, 2019). Kegiatan ini merupakan salah satu bentuk alih media yang digunakan dalam pengelolaan kearsipan sebagai upaya perlindungan terhadap fisik maupun konten dari arsip itu sendiri. Kegiatan ini sesungguhnya memiliki tantangan tersendiri yaitu kuantitas materi yg akan dialih-mediakan, selain itu, kegiatan ini juga membutuhkan peralatan seperti komputer, scanner, printer dan alat perekam lainnya. Kegiatan melakukan konversi data ini dijelaskan lebih lanjut sebagi berikut;

"Digitization is the process of converting any physical or analogue item, such as a paper record, photograph or graphic items, into an electronic representation or image that can be accessed and stored electronically"(ARMS, 2009)

Maksud definisi tersebut ialah digitisasi merupakan proses berbagai fisik atau analog seperti foto, tektual, maupun grafis yang diubah menjadi elektronik yang mana aksesibilitas dan penyimpanannya dilakukan secara elektronik. Pendapat selaras dengan pernyataan tersebut alah :

"Digitization is the process of transforming analogue material into binary electronic form especially for storage and use in computer.In words digitization starts with transformation of the analogue format of a resources to a digital format"(Bontouri, 2017)

Pernyataan tersebut mendefinisikan bahwa alih media dimulai ketika adanya transformasi digital yang pada proses ini mengubah format analog menjadi format digital. Digitisasi merupakan proses untuk menjadikan bahan analog ke bentuk elektronik (digital) yang mana sudah merujuk pada sarana simpan menggunakan sarana komputer.

Proses digitisasi memerlukan sarana pendukung mulai dari perangkat keras sampai dengan perangkat lunak. Sarana diartikan sebagai peralatan dengan berbagai jenis, peralatan kerja, ataupun fasilitas yang dapat digunakan untuk difungsikan sebagai alat utama melaksanakan suatu pekerjaan sedangkan pengertian prasarana merupakan hal-hal penunjang utama terselenggaranya suatu proses (Muhidin \& Winata, 2016). Sarana perangkat keras dapat membantu memproyeksikan produk dokumentasi tersebut menjadi digital dan terbaca oleh sistem komputer.

Kegiatan digitisasi arsip kelurga berarti bahwa melakukan digitisasi arsip dari data kertas menjadi data digital yang disimpan kedalam media simpan yang diinginkan. Arsip keluarga yang dilakukan digitasisasi terbagi kedalam beberapa bentuk antara lain:

1. Arsip pendidikan

Arsip pendidikan merupakan arsip-arsip yang tercipta akibat kegiatan pendidikan dalam suatu keluarga, antara lain: Ijazah, Sertifikat Pelatihan/ Seminar/Workshop, Rapor Nilai, Bukti bayar SPP, dan lain-lain.

2. Arsip Pekerjaan

Arsip perkerjaan merupakan arsip-arsip yang tercippta berkaitan dengan pekerjaan seseornag dalam keluarga, antara lain : Surat Kontrak Kerja, SK PNS, SK Pensiun, dan lain-lain. 


\section{Arsip Kesehatan}

Arsip kesehatan merupakan arsip-arsip yang berkaitan dnegan rekaman kesehatan anggota keluarga, antara lain : Hasil X-Ray, Kartu BPJS, Riwayat Perjalanan, Riwayat Vaksin, Buku Posyandu, Resep Dokter, Kartu Puskesmas, dan lain-lain.

4. Arsip Aset

Arsip aset merupakan bukti kepemilikan keluarga terhadap faktor-faktor ekonomi, seperti : Sertifikat Tanah, BPKP/STNK/SIM, Buku Rekening, dan lainlain.

5. Arsip lain-lain

Arsip lain-lain ini bisa dikatakan merupakan arsip tambahan yang tak kalah penting untuk disimpan karena memiliki nilai guna dan sejarah, seperti ; Foto Keluarga, Lukisan dan lain-lain.

\section{Lesson Learned}

Memahami konteks digitisasi sebagai upaya perlindungan arsip keluarga dimaksudkan untuk memberikan kesadaran pada keluarga bahwa mereka merupakan penyimpan dari arsip-arsip tersebut, selain itu arsip tersebut juga memiliki nilai guna bagi kegiatan internal keluarga tersebut. Beberapa pembelajaran yang dapat diambil antara lain:

1. Pengelolaan arsip merupakan tanggung-jawab keluarga.

Seringkali keluarga atau individu lupa bahwa mereka bertanggung-jawab atas arsip yang mereka simpan atau yang berkaitan dengan mereka. Maka dari itu kegiatan pengabdian ini utamanya merupakan sosialisasi gerakan sadar arsip. Sadar bahwa keluarga menyimpan arsip sehingga pengelolaan yang baik perlu dilakukan. Upaya yang dilakukan oleh tim pengabdian salah satunya adalah dengan menjelaskan jenis-jenis arsip keluarga dan bagaimana mengkelompokannya kedalam klasifikasi sederhana yang dapat digunakan sebagai metode pemberkasan arsip keluarga.

2. Proses Digitisasi merupakan salah satu upaya yang dapat dilakukan untuk melindungi arsip dari kerusakan fisik dan informasi yang terkandung didalamnya.

Kerusakan fisik tidak dapat dihindari terutama pada arsip dengan media kertas. Jamur, debu, kotoran, korosi dari klip kertas, dan kerusakan lain sangat mungkin terjadi. Belum lagi dengan resiko hilang, terselip atau dicuri. Oleh karena itu dengan adanya alih media dari kertas ke digital tentunya sangat membantu untuk keluarga dapat menyimpan salinan dari arsipnya dalam bentuk digital. Selain itu saat ini sudah cukup banyak kegiatan administrasi yang lebih mengedepankan kebutuhan dokumen digital (soft Gile) dari pada bentuk salinan fisiknya (hard file).

3. Dalam pengelolaan arsip perlu dipahami bahwa resiko dan bencana selalu ada dan akan terjadi.

Hidup di Indonesia, terutama di Yogyakarta sangat memungkinkan terjadinya resiko bencana seperti tanah longsor, gempa bumi, banjir ataupun gunung meletus. Hal ini juga berdampak pada penyimpanan arsip keluarga tersebut, apabila arsip telah dialih-mediakan dan disimpan ke penyimpanan elektronik ataupun cloud, tentunya akan lebih aman, karena mudah ditemukan kembali dan tersimpan dengan baik. 


\section{Kegiatan Pengabdian Masyarakat Proses Digitisasi}

Kegiatan pengabdian ini sesungguhnya terbagi dalam 3 tahapan yaitu di tahun 2018, 2019 dan 2020. Masing-masing tahapan memiliki dampak tersendiri yang saling berkaitan. Pada tahun 2018, kegiatan berfokus pada sosialisasi pentingnya pengelolaan arsip keluarga. Tim pengabdian melakukan kegiatan penyuluhan pada RW 1 dengan mengundang ibu-ibu PKK, pada saat itu tanggapan yang diberikan cukup baik. Kelurahan Wates sendiri pada saat itu juga sedang memiliki gerakan sadar arsip, hal ini tentunya mendukung program tim pengabdian karena sesuai dengan tujuan tim tentang kesadaran arsip keluarga.

Pada tahun 2019, kegiatan lebih praktikal. Tim bersama dengan mahasiswa tidak hanya melaksanakan penyuluhan namun juga terjun langsung membantu warga dalam melakukan alih-media arsip-arsip mereka. Target projek ini adalah seluruh arsip keluarga pada RW 1 Dusun Punukan. Namun dikarenakan kendala waktu memang belum semua selesai dikerjaan. Saat itu,w arga dikumpulkan di balai desa setempat dengan diwajibkan membawa arsip-arsip mereka. Mahasiswa membantu untuk melakukan alih media dengan menggunakan saranan pemnindai scanner sekaligus menyimpan soft file tersebut kedalam media flashdisk yang diberikan kepada setiap keluarga yang hadir. Proses digitalisasi arsip keluarga dilaksanakan dengan beberapa tahapan. Yang mana tahapan tersebut adalah sebagai berikut : Persiapan yang dimulai dengan sosialisasi kepada warga tentang program digitalisasi arsip keluarga, kemudian tahap pendataan arsip dengan mengumpulkan arsip keluarga tiap KK dan memilah milih sesuai dengan formulir yang telah disiapkan, lalu tahap digitalisasi arsip itu sendiri yaitu dengan cara menscan untuk selanjutnya disimpan dalam satu folder yang mana terdapat beberapa folder sesuai dengan formulir daftar arsip keluarga seperti A1 (arsip kependudukan), A2, A3 dan lain sebagainya, tahap selanjutnya yaitu penataan fisik arsip kedalam document keeper dan tahap terakhir yaitu penyuluhan dengan mendatangi warga satu per satu dengan membawa arsip yang sudah tertata di Document Keeper. Proyek tentang program digitalisasi arsip keluarga ini dilakukan sebanyak 3 kali yaitu

1. 20 Oktober 2019 Dilakukan dengan door-to-door sehingga kegiatan dilaksanakan di rumah-rumah warga

2. 21 November 2019 Kegiatan memindai dilaksanakan di dua tempat terpusat, sehingga warga datang membawa arsipnya masing-masing.

3. 27 November 2019 Kegiatan dilaksanakan terpusat dirumah Bapak RW dengan dibagi beberapa kelompok. Kelompok yang satu meminta arsip ke tiap tiap rumah. Kelompok yang lain melakukan digitalisasi arsip di Rumah Pak RW. Hasil arsip keluarga yang sudah digitalisasikan sebanyak 31 KK dari 68 KK di RT 2. 


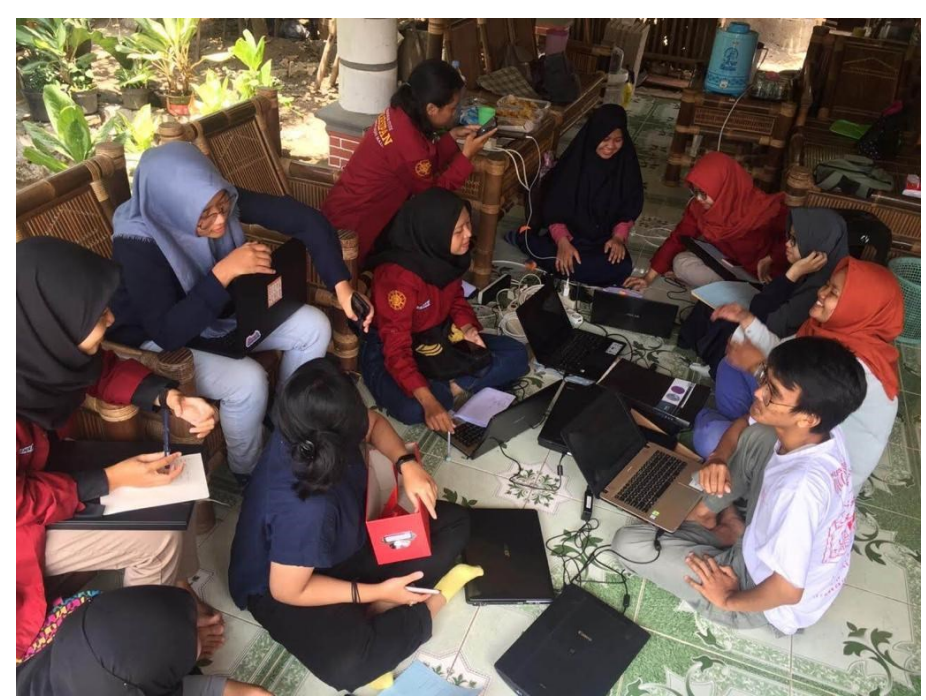

Gambar 1. Proses Digitisasi Arsip Keluarga RW 1 yang Didampingi Mahasiswa Prodi Kearsipan SV UGM Sumber: Dokumentasi Tim Praktikum

Pada tahun 2020, karena kendala pandemi COVID-19 yang terjadi saat ini, kegiatan pengabdian menjadi terbatas dalam ruang geraknya. Hal yang dapat dilakukan pada saat ini adalah melakukan pengabdian dengan tetap mempertimbahkan protokol kesehatan. Pada akhirnya diputuskan bahwa kegiatan pemberian materi dilaksanakan secara mandiri, tim pengabdian menyiapkan materi yang perlu dipahami oleh warga, dan warga akan diperbolehkan mempelajari sendiri. Hal ini nampaknya tidak terlalu berkendala, ketua RW melaporkan bahwa warga tetap antusias mempelajari materi tentang digitisasi arsip keluarga sebagai upaya perlindungan arsip tersebut.

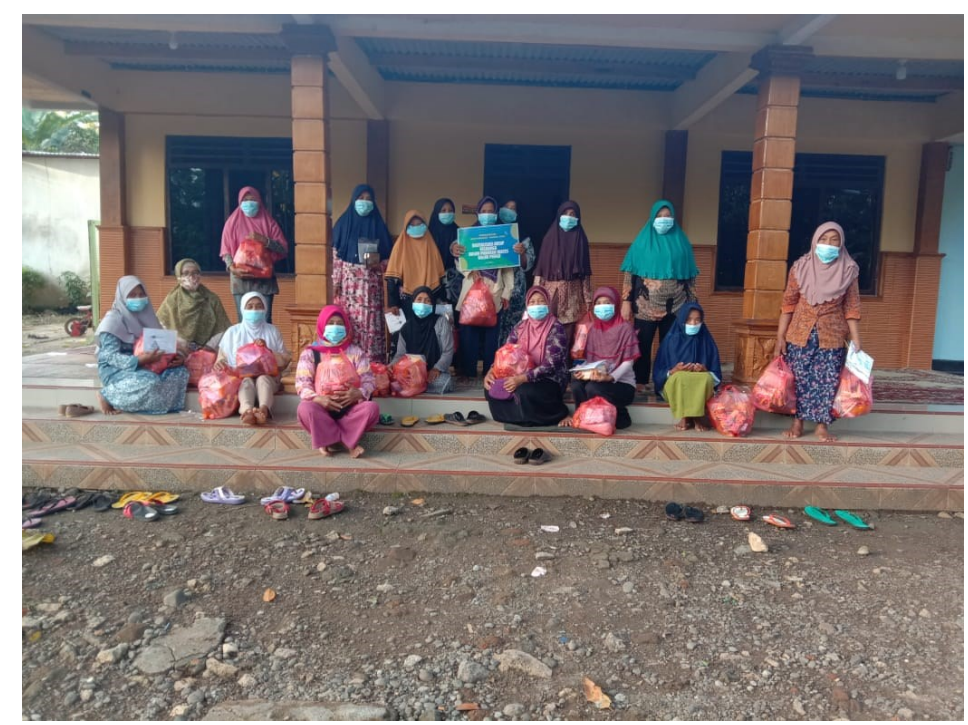

Gambar 2. Kegiatan pengabdian yang tetap menjaga protokol kesehatan Sumber: Dokumentasi Tim Pengabdian 


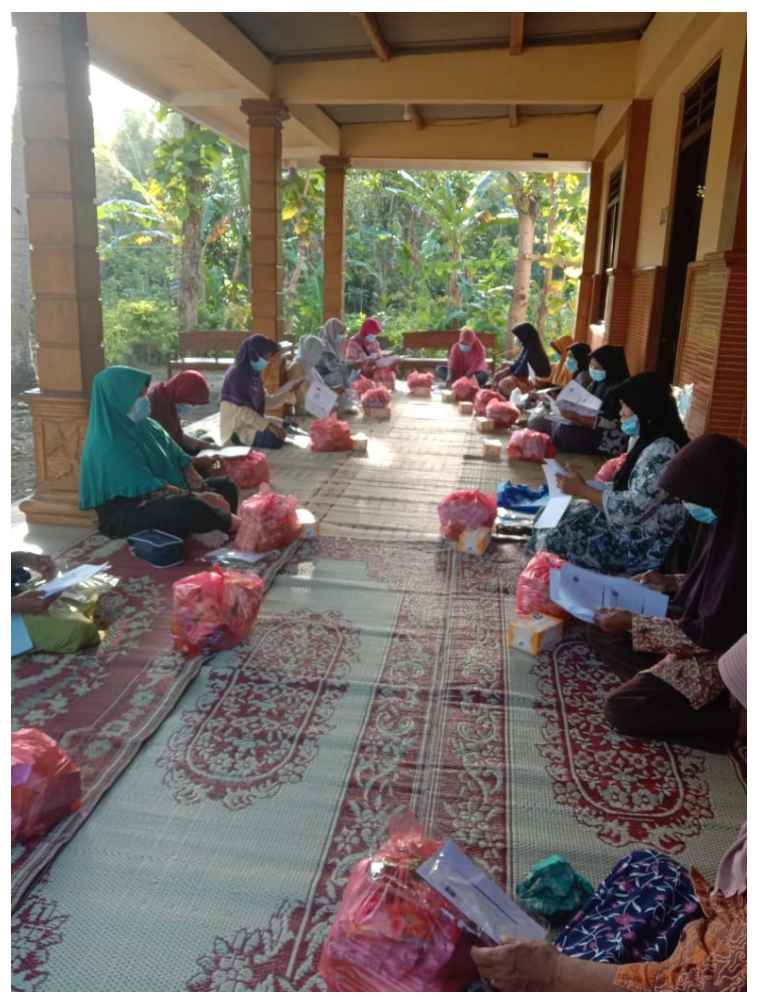

Gambar 3. Masyarakat antusias membaca dan mempelajari sendiri materi yang diberikan, dengan dibantu arahan dari Ketua RW.

Sumber: Dokumentasi Tim Pengabdian

\section{Kendala Proses Digitisasi}

Secara umum, kendala yang dihadapi adalah situasi pandemi yang menyebabkan halangan tatap muka fisik dengan target pengabdian. Sementara secara khusus, ada beberapa kendala dalam proses digitisasi ini , yaitu :

1. Kurangnya koordinasi antar warga sehingga banyak warga yang tidak mengerti terhadap pengabdian atau program digitalisasi arsip keluarga.

2. Kurangnya pemahaman terhadap program ini sehingga banyak warga yang kurang percaya apabila arsip kita digitalisasikan.

3. Kurangnya koordinasi antara warga dengan tim pengabdian sehingga sering misskomunikasi yang berakibat kurang maksimalnya hasil program digitalisasi arsip keluarga ini. Dan juga pihak warga yang susah untuk dihubungi.

4. Jarak yang jauh untuk menempuh ke lokasi tujuan pengabdian masyarakat sehingga waktu banyak terbuang di jalan.

\section{Saran Dalam Peningkatan Keberhasilan Program}

Beberapa saran dapat diberikan untuk meningkatkan kegiatan ini dan juga kebehasilan dari program pengabdian, antara lain adalah :

1. Koordinasi dengan warga yang matang sehingga warga paham terhadap proyek ini dan tidak minimbulkan prasangka yang kurang baik.

2. Persiapan tim dan akomodasi, karena jarak yang ditempuh tidak sebentar maka perlu persiapan yang matang dari segi jumlah personil tim untuk terjun ke rumah -rumah warga, perlengkapan dan akomodasi, serta kepastian jadwal dalam melakukan projek. 


\section{KESIMPULAN}

Pelaksanaan kegiatan pengabdian masyarakat ini telah dilaksanakan prodi Kearsipan sejak 2018 hingga 2020. Adapun tingkat keberhasilan dapat dikatakan cukup signifikan, dengan hasil yang telah diperoleh. Kegiatan digitisasi juga telah dilaksanakan dengan baik, mulai dari pemberian pemahaman tentang pentingnya arsip keluarga, jenis-jenis arsip keluarga dan bagaimana metode perlindungannya. Kegiatan secara praktikal telah dilakukan pada tahun 2019 dnegan melakukan pendampingan dalam konversi data arsip dari media kertas menjadi media digital yang disimpan dalam lashdisk masing-masing keluarga. Pada tahun ini, kegiatan masih berlanjut dengan memberikan sosialisasi tentang urgensi perlindungan arsip keluarga dari berbagai resiko. Metode perlindungan yang ditawarkan masih sama yaitu alih media ke digital. Besar harapan peneliti bahwa program ini tetap berjalan meskipun secara mandiri dari pihak warga agar dapat menumbuhkan kesadaran pada arsip keluarga.

\section{UCAPAN TERIMAKASIH}

Ibu Ponijah selaku ketua RW 1, Dusun Punukan, Wates, Kulonporgo yang telah membantu pelaksanan kegiatan ini sejak 2018 hingga 2020.

\section{DAFTAR PUSTAKA}

ARMS. (2009). Standard Records- Keeping Requirements for Digitization.

Bontouri, L. (2017). Archives In the Digital Age: Standards, Policies and Tools, . Chandos Publishing.

Muhidin, S. A., \& Winata, H. (2016). Manajemen Kearsipan. Pustaka Setia.

Perka ANRI Nomor 6 Tahun 2005 tentang Pengelolaan Arsip Vital

Savic, D. (2019). From Digitization Through Digitalization to Digital Transformation. Online Searcher, 37-39.

Sattar. (2019). Manajemen Kearsipan. Yogyakarta. CV. Budi Utama.

Undang -Undang Nomor 43 Tahun 2009 tentang Kearsipan 